\title{
Total Coliform and Generic E. coli Levels, and Salmonella Presence in Eight Experimental Aquaponics and Hydroponics Systems: A Brief Report Highlighting Exploratory Data
}

\author{
Daniel L. Weller ${ }^{1,2}$, Lauren Saylor ${ }^{3}$ (1) and Paula Turkon ${ }^{3, *}$ \\ 1 Department of Environmental and Forest Biology, State University of New York, Environmental Science and \\ Forestry, Syracuse, NY 13210, USA; wellerd2@gmail.com \\ 2 Department of Biostatistics and Environmental Health, University of Rochester Medical Center, \\ Rochester, NY 14642, USA \\ 3 Department of Environmental Studies and Sciences, Ithaca College, Ithaca, NY 14850, USA; \\ laurensaylor@vermontlaw.edu \\ * Correspondence: pturkon@ithaca.edu
}

Received: 1 July 2020; Accepted: 27 July 2020; Published: 30 July 2020

\begin{abstract}
Although many studies have investigated foodborne pathogen prevalence in conventional produce production environments, relatively few have investigated prevalence in aquaponics and hydroponics systems. This study sought to address this knowledge gap by enumerating total coliform and generic E. coli levels, and testing for Salmonella presence in circulating water samples collected from five hydroponic systems and three aquaponic systems (No. of samples $=79$ ). While total coliform levels ranged between 6.3 Most Probable Number (MPN)/100-mL and the upper limit of detection (2496 MPN/100-mL), only three samples had detectable levels of E. coli and no samples had detectable levels of Salmonella. Of the three E. coli positive samples, two samples had just one MPN of E. coli/100-mL while the third had 53.9 MPN of E. coli/100-mL. While the sample size reported here was small and site selection was not randomized, this study adds key data on the microbial quality of aquaponics and hydroponics systems to the literature. Moreover, these data suggest that contamination in these systems occurs at relatively low-levels, and that future studies are needed to more fully explore when and how microbial contamination of aquaponics and hydroponic systems is likely to occur.
\end{abstract}

Keywords: aquaponics; salmonella; Escherichia coli (E. coli); hydroponics; food safety; produce safety

\section{Introduction}

Multiple foodborne disease outbreaks and recalls have been traced back to preharvest contamination of fresh produce (e.g., [1-3]). For example, several recent Escherichia coli (E. coli) O157:H7 outbreaks linked to romaine lettuce have been traced back to the use of contaminated irrigation water [4,5]; the 2018 outbreak linked to lettuce grown in Yuma, AZ resulted in 210 illnesses, 96 hospitalizations, and 5 deaths across 36 states [5]. Due to the substantial public health and economic burden of produce-associated outbreaks, preventing preharvest contamination is a priority for academic, government, and industry stakeholders [6,7]. Indeed, multiple studies have been conducted to investigate the prevalence, distribution, and dispersal of foodborne pathogens in and between farm and farm-adjacent environments [8-10]. For instance, a series of studies conducted in California and New York examined the transfer of E. coli from wildlife feces to preharvest lettuce via splash during irrigation [11-14]. Similar field studies have been conducted to examine pathogen 
survival in and transfer to produce from soil, irrigation water, and other environmental sources [15-21]. However, the majority of research has focused on soil-based field and greenhouse environments, and there is limited data on food safety hazards in soil-free production environments, such as hydroponics (i.e., production of plants in a liquid media instead of soil) and aquaponics (i.e., system that combines aquaculture [raising of fish or other seafood] with hydroponics) systems. Indeed, a recent topical summit that gathered academic, industry and government experts identified the need for additional data on hazards in hydroponic and aquaponics systems, and specialized resources for growers who utilize these systems [22].

Although relatively few studies have investigated the prevalence and distribution of food safety hazards in aquaponics systems, these systems are of increasing interest as a way to address food sustainability and security needs. Studies conducted in conventional and greenhouse production environments, and fish supply chains indicate that multiple pathways exist for the introduction of foodborne pathogens into hydroponic and aquaponic systems, including, but not limited to, fish feed, fish waste, the system's water, and the vegetable seeds [3,23-32]. Due to the limited number of studies that investigated food safety hazards in aquaponics or hydroponics systems [27,32-35], additional prevalence data are needed to fully characterize and manage food safety hazards associated with various aquaponics and hydroponics inputs. This need is particularly pressing, since the data that currently exist vary substantially between studies. For example, a study that surveyed pathogen levels in six experimental systems isolated Shiga-toxin producing E. coli but not Listeria monocytogenes or Salmonella from water, fish feces, and produce root samples [27]. Conversely, a study that sampled commercial and backyard aquaponics systems in Hawaii failed to detect E. coli O157:H7 or Salmonella in 510 fish feed, fish, and produce samples [36]. However, an unpublished study from the University of Minnesota did detect Listeria in aquaponically, and hydroponically-grown lettuce at retail [37]. The present study was conducted to generate data on the levels and prevalence of microbial contaminants in three aquaponics and five hydroponics systems in New York, to help address this knowledge gap and to generate preliminary data on which future studies can build. Since past studies have shown that water is a key pathway for the introduction of foodborne pathogens into production environments, and can, directly and indirectly, transfer pathogens to produce [11,13,38-42], the current study specifically focused on characterizing microbial contamination of water in the eight aquaponics and hydroponics systems sampled here.

\section{Methods}

Systems. Water samples were collected from eight experimental systems in Ithaca, New York, including 3 aquaponics and 5 hydroponic systems (Table 1). While all systems were essentially similar in overall design (e.g., use of municipal water), systems differed in size, temperature, and potential for food safety contamination (e.g., presence of foot traffic; open-air; Table 1). Four of the experimental systems (three hydroponic and one koi-based aquaponic system at Location C) were located in a greenhouse with temperature maintained at $16-29^{\circ} \mathrm{C}$, and with limited public access and no food safety protocols (e.g., regarding handwashing prior to interacting with the systems). The fifth system (hydroponics system at Location T) was an open-air system in a large dining establishment providing several hundred individuals access to the system on a daily basis, and resulting in temperature staying at approximately $21-25^{\circ} \mathrm{C}$. The sixth system (a catfish-based aquaponics system) was in an un-insulated greenhouse with minimal foot traffic (air temperature ranged between -1 and 37; Location $\mathrm{H}$ ), while the remaining aquaponics (tilapia-based) and hydroponics systems were in a heated greenhouse (air temperature approximately $19-23^{\circ} \mathrm{C}$ ), utilized water heaters (approximately $19-27^{\circ} \mathrm{C}$ ), and had limited public access. 
Table 1. Characteristics of the eight systems sampled here.

\begin{tabular}{|c|c|c|c|c|c|c|c|c|}
\hline \multirow{2}{*}{ Location } & \multicolumn{2}{|c|}{ System } & \multicolumn{2}{|c|}{ Public Access } & \multicolumn{2}{|c|}{ Temperature Range $\left({ }^{\circ} \mathrm{C}\right)$} & \multirow{2}{*}{ Crop } & \multirow{2}{*}{ Fish } \\
\hline & ID & Type $^{\mathbf{a}}$ & Who & Frequency & Air & Water & & \\
\hline \multirow{4}{*}{$\mathrm{C}$} & $\mathrm{A}$ & Hydroponic & Researchers, Students & Frequent & $16-29$ & $16-29$ & Strawberries & - \\
\hline & B & Hydroponic & Researchers, Students & Frequent & $16-29$ & $60-29$ & Strawberries & - \\
\hline & $\mathrm{C}$ & Hydroponic & Researchers, Students & Frequent & $16-29$ & $16-29$ & Strawberries & - \\
\hline & $\mathrm{D}$ & Aquaponic & Researchers, Students & Frequent & $16-29$ & $16-29$ & Strawberries & 50 Koi \\
\hline $\mathrm{H}$ & $\mathrm{A}$ & Aquaponic & None & Infrequent & $-1-37$ & $4-32$ & Variable & 30 Catfish \\
\hline \multirow{2}{*}{$\mathrm{L}$} & $\mathrm{A}$ & Hydroponic & Researchers, Students & Frequent & $19-23$ & $19-23$ & Basil, Lettuce & - \\
\hline & B & Aquaponic & Researchers, Students & Frequent & $19-23$ & $26-27$ & Basil, Lettuce & 20 Tilapia \\
\hline $\mathrm{T}$ & $\mathrm{A}$ & Hydroponic & Public-Access & Constant & $21-25$ & $21-25$ & Basil & - \\
\hline
\end{tabular}

a Hydroponics refers to a system that produces plants in a liquid media instead of soil. Aquaponics refers to a system that combines aquaculture [raising of fish or other seafood] with hydroponics. 
Sampling and Bacterial Assays. Water samples were collected weekly from seven systems for ten weeks, and from one system for nine weeks; the latter was enrolled after the first set of samples were collected (No. of samples total $=79$ ). Samples were collected between January and March 2018 . At each sampling 100-mL of water was collected from the reservoir used to collect water prior to recirculation. Samples were collected by submerging the sampling bottle $15 \mathrm{~cm}$ below the water surface. Samples were held on ice and processed within $1 \mathrm{~h}$ of sample collection. Total coliform and E. coli (a fecal indicator bacteria [FIB]) concentrations were enumerated in 100-mL of the sample using the IDEXX Colilert Quanti-tray 2000 per manufacturer's instructions and as previously described [43,44]. While there are limitations to this method (e.g., inability to detect viable but non-culturable [VBNC] bacteria), this approach is consistent with current produce safety water quality standards in the United States. Indeed, the IDEXX Colilert Quanti-tray 2000 is an approved method for conducting E. coli testing as proscribed in Food Safety Modernization Act's Produce Safety Rule [45]. Gloves were changed between each sample collection, and all sampling equipment, including the gloved hands, were sterilized with 70\% ethanol. Positive (B-strain E. coli) and negative (sterile water plus Colilert reagent) controls were run in parallel with each sampling set; all negative samples had $<1$ most probable number (MPN) per 100-mL (this was the lower limit of detection [LOD]), while all positive samples had >2419.6 MPN/100-mL (the upper LOD). For one system per week, an additional 25-mL was used for Salmonella detection (i.e., 9 samples were tested for Salmonella in the study reported here). The 25-mL samples collected from systems with detectable levels of $E$. coli were preferentially selected for Salmonella testing. During weeks when all samples were below the lower limit of detection for E. coli, one sample was randomly selected for Salmonella detection. Random selection was performed to ensure that at least one sample per system was sent for Salmonella testing. Samples were shipped on ice to Eurofins Scientific Laboratories, who performed the analyses for Salmonella detection using AOAC method 2003.09 [46]. This method uses the BAX assay as a PCR-screen followed by culture-confirmation of any PCR-positive samples [46]; past studies have used similar methods for detecting Salmonella in water $[43,44]$. Since a PCR-screen is performed before culture-confirmation, the presence of dead and viable but non-culturable (VBNC) Salmonella is possible using this method. However, dead and VBNC cannot be distinguished using this approach. All E. coli and coliforms data are available in Supplemental Materials-Raw Data.

\section{Results and Discussion}

Of the 79 samples collected, $100 \%$ tested positive for coliforms. Specifically, 61 samples were above the upper LOD for the IDEXX Colilert Quanti-Tray 2000 (2419.6 MPN/100-mL). The 16 samples below the upper LOD ranged between 6.3 and 1986.3 MPN of total coliforms/100-mL (mean $=1024.7 \mathrm{MPN} / 100-\mathrm{mL})$. The five samples with the lowest total coliform levels all came from H-A (Table 2). H-A thus had the lowest level of total coliforms of the eight systems sampled and was also the only site without public access or foot traffic. Ninety-six percent (76/79) of samples were below the LOD for generic E. coli (Supplemental Materials-Raw Data; 95\% Confidence Interval $[95 \% \mathrm{CI}]=$ 0-3.7 MPN/100-mL; Table 2). Of the three samples that were above the LOD (1 MPN/100-mL) for generic E. coli, two samples had $1 \mathrm{MPN}$ of E. coli/100-mL (95\% CI $=0.1-5.5 \mathrm{MPN}$ of E. coli/100-mL) and were collected from systems T-A and C-B. The third sample that was above the LOD was collected from system C-C and had 53.9 MPN of E. coli/100-mL (95\% CI = 40.5-69.7 MPN of E. coli/100-mL; Table 2). Of the three samples that were above the LOD, each came from separate systems indicating low-level contamination in multiple systems (Table 2). All nine samples sent for Salmonella testing were below the limit of detection for the test $(\mathrm{LOD}=1 / 25-\mathrm{mL})$, indicating the probable absence of Salmonella in the system at the time of sample collection. 
Table 2. Summary of microbial results for each of the eight systems samples.

\begin{tabular}{|c|c|c|c|c|c|c|c|}
\hline \multirow[b]{3}{*}{ Location } & \multirow{2}{*}{\multicolumn{3}{|c|}{ System }} & \multicolumn{4}{|c|}{ Microbial $^{a}$} \\
\hline & & & & \multicolumn{2}{|c|}{ Total Coliforms } & \multicolumn{2}{|r|}{ E. coli } \\
\hline & ID & Type & $\begin{array}{c}\text { No. of } \\
\text { Samples }\end{array}$ & $\begin{array}{l}\text { No. Below Upper } \\
\text { LOD }^{b}\end{array}$ & $\begin{array}{c}\text { Mean }\left(95 \% \mathrm{CI}^{\mathrm{c}}\right) \\
\text { MPN/100-mL in Samples } \\
\text { Below Upper LOD }\end{array}$ & $\begin{array}{l}\text { No. Above Lower } \\
\text { LOD }^{d}\end{array}$ & $\begin{array}{c}\text { Mean }\left(95 \% \mathrm{CI}^{\mathrm{c}}\right) \\
\text { MPN/100-mL in Samples } \\
\text { Above Lower LOD }\end{array}$ \\
\hline \multirow{4}{*}{$\mathrm{C}$} & $\mathrm{A}$ & Hydroponic & 10 & 1 & $437.1(337.2,555.5)$ & 0 & - \\
\hline & B & Hydroponic & 10 & 1 & $1986.3(1222.0,3300.2)$ & 1 & $1.0(0.1,5.5)$ \\
\hline & $\mathrm{C}$ & Hydroponic & 10 & 1 & $1986.3(1222.0,3300.2)$ & 1 & $53.9(40.5,69.7)$ \\
\hline & $\mathrm{D}$ & Aquaponic & 10 & 1 & $1732.9(1167.7,2709.5)$ & 0 & - \\
\hline $\mathrm{H}$ & A & Aquaponic & 9 & 7 & $354.0(247.0,524.7)$ & 0 & - \\
\hline \multirow{2}{*}{$\mathrm{L}$} & $\mathrm{A}$ & Hydroponic & 10 & 1 & $1553.1(1016.2,2353.1)$ & 0 & - \\
\hline & $\mathrm{B}$ & Aquaponic & 10 & 2 & $1986.3(1222.0,3300.2)$ & 0 & - \\
\hline $\mathrm{T}$ & $\mathrm{A}$ & Hydroponic & 10 & 2 & $1124.6(788.1,1678.9)$ & 1 & $1.0(0.1,5.5)$ \\
\hline
\end{tabular}

${ }^{\text {a }}$ One 25-mL sample per system was tested for Salmonella presence (No. of Samples $=9$ ), and none were positive. ${ }^{b}$ Upper limit of detection (LOD) $=2419.6 \mathrm{MPN} / 100-\mathrm{mL}$. ${ }^{\mathrm{c}}$ 95\% confidence interval. If all samples were above or below the LOD then-was entered. ${ }^{\mathrm{d}}$ Lower LOD $=1 \mathrm{MPN} / 100-\mathrm{mL}$ 
Due to the limited number of samples positive for generic E. coli or Salmonella, and below the upper LOD for total coliforms no statistical analyses could be performed here. While the limited sample size ( $N=79$ for samples where FIBs were enumerated, and $N=9$ for samples where pathogen testing was performed) is a limitation of the study reported here, preliminary studies, including negative results, provide key data on which future studies can build. Indeed, despite the presence of potential risk factors for microbial contamination (e.g., public access, absence of handwashing protocols), fecal contamination (as indicated by E. coli, a fecal indicator bacteria) was detected in $4 \%$ of samples. Future research on pathogen prevalence in aquaponics and hydroponics systems can use these data to guide sample size calculations for their studies. For instance, based on the $4 \%$ prevalence found here, a future study that wanted to estimate E. coli prevalence in aquaponics and hydroponics systems with $95 \%$ confidence and $2 \%$ precision, would need to collect 188 samples (sample size estimation performed using formula in [47]). If a higher precision or confidence is desired then the necessary sample size would increase ( $1 \%$ precision increases sample size to $753,97.5 \%$ confidence increases sample size to 224).

Despite the small sample size of the study reported here, the results are consistent with the findings of several past studies [32-34]. For example, a study that collected basil, lettuce, barramundi and water from 6 laboratory aquaponics-systems over 118 days failed to detect generic E. coli, E. coli O157:H7, or Salmonella in any of the samples [34]. This previous study, like the study reported here, found similar levels of coliforms (between 13 and 1820 CFU/100-g; calculated using data reported in the study; [34]). Also similar to the study reported here, a study that assessed microbial contamination on lettuce and water samples collected from two Puerto Rican hydroponic facilities failed to detect Salmonella [32].

Interestingly, the low levels of microbial contamination reported here and in previous aquaponics and hydroponics studies, contrasts to the substantially higher levels of microbial contamination reported by studies conducted in conventional production environments. For example, all 181 agricultural water samples collected from conventional produce farm environments in New York in a 2017 study had detectable levels E. coli $($ Mean $=181.5 \mathrm{MPN} / 100-\mathrm{mL}$; Range $=18.5$ to $>2419.6 \mathrm{MPN} / 100-\mathrm{mL}$ ), while $44 \%$ (80/181) of samples were Salmonella-positive. The two agricultural water studies are not unique as multiple studies conducted in Arizona [44], Belgium [10], Florida [48], New York [40,43], South Africa [49], Spain [50], and Virginia [51] also reported higher fecal indicator bacterial levels and higher pathogen prevalence than the present study. While this may suggest a lower likelihood of food safety hazards in aquaponic and hydroponic systems compared to conventional agriculture, additional studies are needed to directly compare food safety hazards in these to conventional environments. Despite this need for additional research, the results of this and other aquaponics/hydroponics food safety studies indicate that contamination in aquaponics/hydroponics systems occurs at low-levels [32-34], and that large sample sizes are needed in future observational studies to fully characterize pathogen prevalence in these systems.

Supplementary Materials: The following are available online at http://www.mdpi.com/2311-7524/6/3/42/s1, Table: Raw Data.

Author Contributions: P.T. obtained funding. P.T., D.L.W., and L.S. designed the study. L.S. collected the data. D.W. wrote the manuscript, and all authors proofread the manuscript. All authors have read and agreed to the published version of the manuscript.

Funding: This project was made possible by an Academic Challenge Grant awarded by the Office of the Provost at Ithaca College and by IDEXX Laboratories through the loan of the material needed for fecal indicator enumeration. Manuscript preparation was also supported by the National Institute of Environmental Health Sciences of the National Institutes of Health (NIH) under award number T32ES007271. The content is solely the responsibility of the authors and does not represent the official views of the NIH.

Acknowledgments: We would like to thank Srijana Bajracharya, Susan Allen-Gil, and the owners/operators of the aquaponics and hydroponics systems sampled here.

Conflicts of Interest: The authors declare no conflict of interest. 


\section{References}

1. Zhu, Q.; Gooneratne, R.; Hussain, M. Listeria monocytogenes in Fresh Produce: Outbreaks, Prevalence and Contamination Levels. Foods 2017, 6, 21. [CrossRef] [PubMed]

2. Herman, K.M.; Hall, A.J.; Gould, L.H. Outbreaks attributed to fresh leafy vegetables, United States, 1973-2012. Epidemiol. Infect. 2015, 143, 3011-3021. [CrossRef] [PubMed]

3. Harris, L.J.; Farber, J.N.; Beuchat, L.R.; Parish, M.E.; Suslow, T.V.; Garrett, E.H.; Busta, F.F. Outbreaks associated with fresh produce: Incidence, growth, and survival of pathogens in fresh and fresh-cut produce. Compr. Rev. Food Sci. Food Saf. 2003, 2, 78-141. [CrossRef]

4. Food and Drug Administration. Investigation Summary: Factors Potentially Contributing to the Contamination of Romaine Lettuce Implicated in the Fall 2018 Multi-State Outbreak of E. coli O157:H7; Food and Drug Administration: Maryland, MD, USA, 2019.

5. Food and Drug Administration. FDA Investigated Multistate Outbreak of E. coli O157:H7 Infections Linked to Romaine Lettuce from Yuma Growing Region; Center for Food Safety and Applied Nutrition: Washington, DC, USA, 2018.

6. Arnade, C.; Calvin, L.; Kuchler, F. Consumer response to a food safety shock: The 2006 foodborne illness outbreak of E. coli O157: H7 linked to spinach. Rev. Agric. Econ. 2009, 31, 734-750. [CrossRef]

7. Calvin, L.; Jensen, H.; Klonsky, K.; Cook, R. Food Safety Practices and Costs under the California Leafy Greens Marketing Agreement; USDA ERS: Washington, DC, USA, 2017.

8. Luo, Z.; Gu, G.; Ginn, A.; Giurcanu, M.C.; Adams, P.; Vellidis, G.; van Bruggen, A.H.C.; Danyluk, M.D.; Wright, A.C. Distribution and characterization of Salmonella enterica isolates from irrigation ponds in the southeastern United States. Appl. Environ. Microbiol. 2015, 81, 4376-4387. [CrossRef] [PubMed]

9. Benjamin, L.; Atwill, E.R.; Jay-Russell, M.; Cooley, M.; Carychao, D.; Gorski, L.; Mandrell, R.E. Occurrence of generic Escherichia coli, E. coli $\mathrm{O} 157$ and Salmonella spp. in water and sediment from leafy green produce farms and streams on the central California coast. Int. J. Food Microbiol. 2013, 165, 65-76. [CrossRef] [PubMed]

10. Holvoet, K.; Sampers, I.; Seynnaeve, M.; Jacxsens, L.; Uyttendaele, M. Agricultural and management practices and bacterial contamination in greenhouse versus open field lettuce production. Int. J. Environ. Res. Public Health 2015, 12, 32-63. [CrossRef]

11. Weller, D.L.; Kovac, J.; Kent, D.J.; Roof, S.; Tokman, J.I.; Mudrak, E.; Wiedmann, M. A conceptual framework for developing recommendations for no-harvest buffers around in-field feces. J. Food Prot. 2019, 82, 1052-1060. [CrossRef]

12. Weller, D.L.; Kovac, J.; Kent, D.J.; Roof, S.; Tokman, J.I.; Mudrak, E.; Kowalcyk, B.; Oryang, D.; Aceituno, A.; Wiedmann, M. Escherichia coli transfer from simulated wildlife feces to lettuce during foliar irrigation: A field study in the Northeastern United States. Food Microbiol. 2017, 68, 24-33. [CrossRef]

13. Atwill, E.R.; Chase, J.A.; Oryang, D.; Bond, R.F.; Koike, S.T.; Cahn, M.D.; Anderson, M.; Mokhtari, A.; Dennis, S. Transfer of Escherichia coli O157:H7 from simulated wildlife scat onto romaine lettuce during foliar irrigation. J. Food Prot. 2015, 78, 240-247. [CrossRef]

14. Jeamsripong, S.; Chase, J.A.; Jay-Russell, M.T.; Buchanan, R.L.; Atwill, E.R. Experimental in-field transfer and survival of escherichia coli from animal feces to romaine lettuce in Salinas valley, California. Microorganisms 2019, 7, 408. [CrossRef]

15. Xu, A.; Buchanan, R.L.; Micallef, S.A. Impact of mulches and growing season on indicator bacteria survival during lettuce cultivation. Int. J. Food Microbiol. 2016, 224, 28-39. [CrossRef] [PubMed]

16. Moyne, A.L.; Sudarshana, M.R.; Blessington, T.; Koike, S.T.; Cahn, M.D.; Harris, L.J. Fate of Escherichia coli O157:H7 in field-inoculated lettuce. Food Microbiol. 2011, 28, 1417-1425. [CrossRef] [PubMed]

17. Cevallos-Cevallos, J.M.; Danyluk, M.D.; Gu, G.; Vallad, G.E.; van Bruggen, A.H.C. Dispersal of Salmonella typhimurium by rain splash onto tomato plants. J. Food Prot. 2012, 75, 472-479. [CrossRef]

18. Cevallos-Cevallos, J.M.; Gu, G.; Danyluk, M.D.; Dufault, N.S.; van Bruggen, A.H.C. Salmonella can reach tomato fruits on plants exposed to aerosols formed by rain. Int. J. Food Microbiol. 2012, 158, 140-146. [CrossRef]

19. Cevallos-Cevallos, J.M.; Gu, G.; Danyluk, M.D.; van Bruggen, A.H.C. Adhesion and splash dispersal of Salmonella enterica Typhimurium on tomato leaflets: Effects of rdar morphotype and trichome density. Int. J. Food Microbiol. 2012, 160, 58-64. [CrossRef] [PubMed] 
20. Leon, J.; Bartz, F.; Newman, K.; Hodge, D. Contamination of fresh produce by microbial indicators on farms and in packing facilities: Elucidation of environmental routes. J. Title Appl. Environ. Microbiol. 2017, 83. [CrossRef]

21. Tomás-Callejas, A.; López-Velasco, G.; Camacho, A.B.; Artés, F.; Artés-Hernández, F.; Suslow, T.V. Survival and distribution of Escherichia coli on diverse fresh-cut baby leafy greens under preharvest through postharvest conditions. Int. J. Food Microbiol. 2011, 151, 216-222. [CrossRef]

22. Wall, G.; Clements, D.; Fisk, C.; Stoeckel, D.; Woods, K.; Bihn, E. Meeting Report: Key Outcomes from a Collaborative Summit on Agricultural Water Standards for Fresh Produce. Compr. Rev. Food Sci. Food Saf. 2019, 18. [CrossRef]

23. Hanning, I.B.; Nutt, J.D.; Ricke, S.C. Salmonellosis outbreaks in the United States due to fresh produce: Sources and potential intervention measures. Foodborne Pathog. Dis. 2009, 6, 635-648. [CrossRef]

24. Shaw, A.; Helterbran, K.; Evans, M.R.; Currey, C. Growth of Escherichia coli O157:H7, Non-O157 Shiga toxin-producing Escherichia coli, and salmonella in water and hydroponic fertilizer solutions. J. Food Prot. 2016, 79, 2179-2183. [CrossRef] [PubMed]

25. Soon, J.M.; Seaman, P.; Baines, R.N. Escherichia coli O104:H4 outbreak from sprouted seeds. Int. J. Hyg. Environ. Health 2013, 216, 346-354. [CrossRef] [PubMed]

26. Geldreich, E.E.; Clarke, N.A. Bacterial Pollution Indicators in the Intestinal Tract of Freshwater Fish. Appl. Environ. Microbiol. 1966, 14, 429-437. [CrossRef]

27. Wang, Y.-J.; Deering, A.J.; Kim, H.-J. The Occurrence of Shiga Toxin-Producing E. coli in Aquaponic and Hydroponic Systems. Horticulturae 2020, 6, 1. [CrossRef]

28. Molina, A.; Granados-Chinchilla, F.; Jiménez, M.; Acuña-Calvo, M.T.; Alfaro, M.; Chavarría, G. Vigilance for Salmonella in Feedstuffs Available in Costa Rica: Prevalence, Serotyping and Tetracycline Resistance of Isolates Obtained from 2009 to 2014. Foodborne Pathog. Dis. 2016, 13, 119-127. [CrossRef]

29. McCoy, E.; Morrison, J.; Cook, V.; Johnston, J.; Eblen, D.; Guo, C. Foodborne agents associated with the consumption of aquaculture catfish. J. Food Prot. 2011, 74, 500-516. [CrossRef]

30. Bibi, F.; Qaisrani, S.N.; Ahmad, A.N.; Akhtar, M.; Khan, B.N.; Ali, Z. Occurrence Of Salmonella In Freshwater Fishes: A Review. J. Anim. Plant Sci 2015, 25, 303-310.

31. Petreska, M.; Ziberoski, J.; Zekiri, M. Fish Feed Microbiological Status. J. Hyg Eng Design. 2013, 4, 16-19.

32. Díaz Rivera, M.E.; Vélez, C.; Zayas, B.; Malavé Llamas, K. Bacterial Assessment on Leaves of Green Vegetable Grown on Hydroponics and its possible Health Risks. J. Agric. Environ. Sci. 2015, 4, 1-7. [CrossRef]

33. Sirsat, S.; Neal, J. Microbial Profile of Soil-Free versus In-Soil Grown Lettuce and Intervention Methodologies to Combat Pathogen Surrogates and Spoilage Microorganisms on Lettuce. Foods 2013, 2, 488-498. [CrossRef]

34. Elumalai, S.; Shaw, A.; Pattillo, D.; Currey, C.; Rosentrater, K.; Xie, K. Influence of UV Treatment on the Food Safety Status of a Model Aquaponic System. Water 2017, 9, 27. [CrossRef]

35. Koo, O.K.; Kim, H.; Kim, H.J.; Baker, C.A.; Ricke, S.C. Bacterial community analysis of Tatsoi cultivated by hydroponics. J. Environ. Sci. Heal.-Part B Pestic. Food Contam. Agric. Wastes 2016, 51, 490-496. [CrossRef] [PubMed]

36. Fox, B.K.; Tamaru, C.S.; Hollyer, J.; Castro, L.F.; Fonseca, J.M.; Jay-Russell, M.; Low, T. A preliminary study of microbial water quality related to food safety in recirculating aquaponic fish and vegetable production systems. Food Saf. Technol. 2012, 51, 1-11.

37. Barnhart, C.; Hayes, L.; Ringle, D. Food Safety Hazards Associated with Smooth-Textured Leafy Greens Produced in Aquaponic, Hydroponic, and Soil-Based Systems with and without Roots at Retail Goal of the Project; University of Minnesota Aquaponics: Minneapolis, MN, USA, 2015.

38. Weller, D.; Wiedmann, M.; Strawn, L.K. Irrigation is significantly associated with an increased prevalence of Listeria monocytogenes in produce production environments in New York State. J. Food Prot. 2015, 78, 1132-1141. [CrossRef] [PubMed]

39. Park, S.; Navratil, S.; Gregory, A.; Bauer, A.; Srinath, I.; Jun, M.; Szonyi, B.; Nightingale, K.; Anciso, J.; Ivanek, R. Generic Escherichia coli contamination of spinach at the preharvest stage: Effects of farm management and environmental factors. Appl. Environ. Microbiol. 2013, 79, 4347-4358. [CrossRef] [PubMed]

40. Weller, D.; Wiedmann, M.; Strawn, L. Spatial and temporal factors associated with an increased prevalence of L. monocytogenes in spinach fields in New York State. Appl. Environ. Microbiol. 2015, 81, 6059-6069. [CrossRef] 
41. Lapidot, A.; Yaron, S. Transfer of Salmonella enterica serovar Typhimurium from contaminated irrigation water to parsley is dependent on curli and cellulose, the biofilm matrix components. J. Food Prot. 2009, 72, 618-623. [CrossRef]

42. Ijabadeniyi, O.A.; Debusho, L.K.; Vanderlinde, M.; Buys, E.M. Irrigation water as a potential preharvest source of bacterial contamination of vegetables. J. Food Saf. 2011, 31, 452-461. [CrossRef]

43. Weller, D.; Belias, A.; Green, H.; Roof, S.; Wiedmann, M. Landscape, Water Quality, and Weather Factors Associated With an Increased Likelihood of Foodborne Pathogen Contamination of New York Streams Used to Source Water for Produce Production. Front. Sustain. Food Syst. 2020, 3, 124. [CrossRef]

44. Weller, D.; Brassill, N.; Rock, C.; Ivanek, R.; Mudrak, E.; Roof, S.; Ganda, E.; Wiedmann, M. Complex Interactions Between Weather, and Microbial and Physicochemical Water Quality Impact the Likelihood of Detecting Foodborne Pathogens in Agricultural Water. Front. Microbiol. 2020, 11. [CrossRef]

45. Food and Drug Administration. Standards for the Growing, Harvesting, Packing, and Holding of Produce for Human Consumption; Food and Drug Administration: Maryland, MD, USA, 2015; pp. 74353-74672.

46. Department of Agriculture and Water Resources. BAX Automated System for Screening Salmonella in Foods-AOAC 2003.09 P R I N C I P L E S; Department of Agriculture and Water Resources: Canberra, Australia, 2003.

47. Naing, L.; Winn, T.; Rusli, B.N. Practical issues in calculating the sample size for prevalence studies. Arch. Orofac. Sci. 2006, 1, 9-14.

48. McEgan, R.; Mootian, G.; Goodridge, L.D.; Schaffner, D.W.; Danyluk, M.D. Predicting Salmonella populations from biological, chemical, and physical indicators in Florida surface waters. Appl. Environ. Microbiol. 2013, 79, 4094-4105. [CrossRef] [PubMed]

49. Gemmell, M.E.; Schmidt, S. Microbiological assessment of river water used for the irrigation of fresh produce in a sub-urban community in Sobantu, South Africa. Food Res. Int. 2012, 47, 300-305. [CrossRef]

50. Castro-Ibáñez, I.; Gil, M.I.; Tudela, J.A.; Ivanek, R.; Allende, A. Assessment of microbial risk factors and impact of meteorological conditions during production of baby spinach in the Southeast of Spain. Food Microbiol. 2015, 49, 173-181. [CrossRef] [PubMed]

51. Truitt, L.N.; Vazquez, K.M.; Pfunter, R.C.; Rideout, S.L.; Havelaar, A.H.; Strawn, L.K. Microbial Quality of Agricultural Water Used in Produce Preharvest Production on the Eastern Shore of Virginia. J. Food Prot. 2018, 81, 1661-1672. [CrossRef] [PubMed] 